\title{
Memanfaatkan Gadget Untuk Belajar Bahasa Inggris
}

\section{Oleh Nanang Bagus Subekti}

Versi online artikel: https://englishjogia.com/blog/view/9615/memanfaatkan-gadget-untuk-belajarbahasa-inggris

\section{Untuk dikutip:}

Subekti, N.B. (2018). Memanfaatkan Gadget Untuk Belajar Bahasa Inggris, https://englishjogja.com/blog/view/9615/memanfaatkan-gadget-untuk-belajar-bahasa-inggris

Untuk memudahkan belajar bahasa Inggris, kita memerlukan media. Salah satu media yang kita pilih adalah gadget yang sudah menjadi barang yang tidak terpisahkan dari kehidupan kita sehari-hari. Gadget seperti smartphone atau telpon pintar telah hadir dengan kemampuan seperti komputer pada umumnya. Uniknya smartphone mudah dibawa ke mana-mana dibandingkan computer.

Perkembangan teknologi smartphone memang luar biasa. Dari perangkat yang awalnya hanya sebatas untuk telpon dan SMS, kini smartphone telah hadir dengan fitur-fitur yang lengkap. Berbagai aplikasi pintar telah hadir untuk dipergunakan dari yang gratisan sampai berbayar. Dukungan teknologi internet $4 G$ membuat koneksi semakin ngacir, tidak ada lagi buffering saat menonton video online. Memory (RAM) dan penyimpanan yang dibenamkan di smartphone juga semakin tinggi, bahkan bisa ditambahkan dengan external memory dengan kapasitas yang besar.

Dengan hadirnya teknologi yang luar biasa ini tentu sangat ironis jika kita memiliki smartphone yang spesifikasnya tinggi, namun hanya dipergunakan layaknya smartphone jadul, yaitu sebatas SMS, dan telpon saja. Mengapa tidak dipergunakan secara maksimal sebagai media belajar? Ada banyak keunggulan dari smartphone untuk dipergunakan sebagai media belajar, misalnya: 
1. Koneksi internet yang cepat bisa dipergunakan untuk menonton video-video pembelajaran bahasa Inggris secara online, bergabung dengan komunitas online, membaca berita-berita berbahasa Inggris dll. Hal ini lebih menguntungkan karena biaya atau harga kuota data koneksi internet semakin lama-semakin terjangkau. Di beberapa lokasi umum seperti taman-taman milik pemerintah, kampus-kampus bahkan sampai warung-warung juga telah memberikan fasilitas koneksi internet / wi-fi gratis.

2. RAM yang besar mampu menjalankan aplikasi cukup banyak secara bersamaan, seperti aplikasi pembelajaran bahasa Inggris yang meliputi games berbagai permainan dalam bahasa Inggris, kamus-kamus bahasa Inggris online dll.

3. Memory internal / eksternal yang besar bisa dipergunakan untuk menyimpan file-file elektronik yang banyak seperti e-book, pdf, ms word dll. Kita tidak lagi harus membawa buku-buku cetak (printed) kemana-mana.

4. Spesifikasi yang mumpuni bisa untuk menjalankan berbagai aplikasi media sosial (medsos) sehingga bisa membentuk komunitas online untuk bersama - sama latihan belajar dan menggunakan bahasa Inggris.

5. Hadirnya aplikasi-aplikasi pendukung yang bisa diunduh, baik dari yang gratisan sampai yang berbayar.

6. Smartphone modern hadir dengan ukuran layar yang memudahkan untuk belajar dan bekerja. Hal ini cocok dipergunakan oleh mahasiswa yang senang membaca dan berbagai aktivitas online.

Masih ada banyak manfaat dari penggunaan smartphone sebagai media belajar bahasa Inggris yang belum dibahas di laman ini. Manfaat tersebut akan dibahas di artikel-artikel berikutnya. 